University of Nebraska - Lincoln

DigitalCommons@University of Nebraska - Lincoln

Faculty Publications from the Harold W. Manter Laboratory of Parasitology

4-1993

\title{
Coccidia (Apicomplexa), Genetic Diversity, and Environmental Unpredictability of Four Chromosomal Species of the Subterranean Superspecies Spalax ehrenbergi (Mole-Rat) in Israel
}

\author{
Lee Couch \\ University of New Mexico, Icouch@unm.edu \\ Donald W. Duszynski \\ University of New Mexico, eimeria@unm.edu \\ Eviatar Nevo \\ University of Haifa
}

Follow this and additional works at: https://digitalcommons.unl.edu/parasitologyfacpubs

Part of the Parasitology Commons

Couch, Lee; Duszynski, Donald W.; and Nevo, Eviatar, "Coccidia (Apicomplexa), Genetic Diversity, and Environmental Unpredictability of Four Chromosomal Species of the Subterranean Superspecies Spalax ehrenbergi (Mole-Rat) in Israel" (1993). Faculty Publications from the Harold W. Manter Laboratory of Parasitology. 164.

https://digitalcommons.unl.edu/parasitologyfacpubs/164

This Article is brought to you for free and open access by the Parasitology, Harold W. Manter Laboratory of at DigitalCommons@University of Nebraska - Lincoln. It has been accepted for inclusion in Faculty Publications from the Harold W. Manter Laboratory of Parasitology by an authorized administrator of DigitalCommons@University of Nebraska - Lincoln. 


\title{
COCCIDIA (APICOMPLEXA), GENETIC DIVERSITY, AND ENVIRONMENTAL UNPREDICTABILITY OF FOUR CHROMOSOMAL SPECIES OF THE SUBTERRANEAN SUPERSPECIES SPALAX EHRENBERGI (MOLE-RAT) IN ISRAEL
}

\author{
Lee Couch, Donald W. Duszynski, and Eviatar Nevo* \\ Department of Biology, The University of New Mexico, Albuquerque, New Mexico 87131
}

\begin{abstract}
Forty-five mole-rats, representing 4 chromosomal species $(2 n=52,54,58,60)$ of the superspecies Spalax ehrenbergi, were collected from 12 localities in Israel in 4 distinct climatic regions. Feces were examined for coccidian oocysts and $41(91 \%)$ were infected; $26(63 \%)$ had multiple infections of up to 5 coccidian species, 4 of which are described here as new species. Sporulated oocysts of Eimeria anzanensis n. sp. were ellipsoidal $18.3 \times 12.5 \mu \mathrm{m}(14-22 \times 10-16)$ and had elongate-ovoidal sporocysts $7.3 \times 4.9 \mu \mathrm{m}(5-10 \times 3-7)$; it occurred in 39 of $45(87 \%)$ mole-rats, including all chromosomal species. Sporulated oocysts of Eimeria spalacensis n. sp. were ovoidal $23.4 \times 18.3 \mu \mathrm{m}(17-29 \times 12-21)$ with ovoidal sporocysts $9.4 \times 6.8 \mu \mathrm{m}(6-12 \times 4-10)$; it occurred in 7 of $45(16 \%)$ mole-rats $(2 n=54,58,60)$. Sporulated oocysts of Eimeria carmelensis $\mathrm{n}$. sp. were subspheroidal to ellipsoidal $19.1 \times 16.5 \mu \mathrm{m}(14-25 \times 11-20)$ and had sporocysts that were spheroidal to ellipsoidal $8.6 \times 6.2 \mu \mathrm{m}(6-13 \times 4-8)$; it occurred in 5 of $45(11 \%)$ mole-rats $(2 \mathrm{n}=58,60)$. Sporulated oocysts of Isospora spalacensis $\mathrm{n}$. sp. were ellipsoidal $14.6 \times 11.0 \mu \mathrm{m}(12-17 \times 9-14)$ with ellipsoidal to ovoidal sporocysts $8.5 \times 4.5 \mu \mathrm{m}(7.5-11 \times 4-7)$; it occurred in 5 of $45(11 \%)$ mole-rats $(2 \mathrm{n}=58,60)$. Twenty-five of $45(56 \%)$ mole-rats (all 4 species) were infected with a previously described form, Eimeria elliptica Sayin, Dincer, and Meric, 1977. The genetic diversity of mole-rats in Israel is known to increase chromosomally $(2 \mathrm{n}=52 \rightarrow$ 60 ) and genically (heterozygosity $[\mathrm{H}]=0.035 \rightarrow 0.069$ ) as the environment becomes more demanding (i.e., increasingly warm, dry, and climatically unpredictable). At the same time, there is an increased diversity of coccidian parasites. This suggests correlation among host chromosomal variability, habitat, and increased prevalence of multiple infections, a pattern also seen in other fossorial rodents infected with coccidia.
\end{abstract}

Between 1988 and 1990, mole-rats of the Spalax ehrenbergi Nehring superspecies (see Nevo, $1985,1991)$ were collected in Israel and examined for coccidian parasites. Members of this subterranean rodent superspecies are morphologically indistinguishable, yet constitute 4 chromosomally homozygous species that exhibit adaptive radiation associated with diverse climatic regions (Nevo, 1986, 1991). Although the genetics of $S$. ehrenbergi from Israel have been well studied (Nevo and Shaw, 1972; Nevo and Cleve, 1978; Wahrman et al., 1985), only 3 papers have been written about the parasites of these hosts (Costa and Nevo, 1969 [arthropods]; Wertheim and Nevo, 1971 [nematodes]; Fair et al., 1990 [a cestode]); there is no study to date on the coccidia that infect these chromosomal species.

Brooks (1979) proposed that coaccommodation and cospeciation between hosts and their parasites may be representative of mutual descent. Thus, we were interested in examining these

Received 24 August 1992; revised 16 November 1992; accepted 16 November 1992.

* Institute of Evolution, University of Haifa, Mount Carmel, Haifa 31905, Israel. chromosomal species of Spalax to learn if there was any correlation between host chromosomal variability and parasite-host specificity or parasite-host climate dependency as further evidence of a coevolutionary trend. With this in mind, we looked at samples of the known chromosomal species from each climatic locality. Three new species of Eimeria and 1 of Isospora are described, Eimeria elliptica Sayin, Dincer, and Meric, 1980, is described for the first time from $S$. ehrenbergi, and the relationships of these coccidians to their hosts' genetic makeups and environments are discussed.

\section{MATERIALS AND METHODS}

Mole-rats comprising 4 chromosomal species of the superspecies $S$. ehrenbergi, from 4 climatic regions in Israel, were live-caught by hand and fecal samples from the small intestine, cecum, and colon collected upon necropsy. Fecal samples were placed in separate vials containing $2 \%(\mathrm{w} / \mathrm{v})$ aqueous potassium dichromate $\left(\mathrm{K}_{2} \mathrm{Cr}_{2} \mathrm{O}_{7}\right)$, mixed thoroughly, and stored at ambient temperature. Upon receiving the samples in Albuquerque, they were processed, and oocysts were stored, measured, and photographed as detailed by Duszynsk et al. (1982). All measurements are given in micrometers with size ranges in parentheses following the means. Karyotypes of mole-rats from the different climatic regions were as described previously (see Wahrman et al., 1985). Host carcasses were preserved either in alcohol or frozen and are deposited at the Institute 
of Evolution, University of Haifa, Haifa, Israel (IEUH), under the name and collection number of the collector, along with the date of collection.

\section{RESULTS}

Forty-five mole-rats of the superspecies $S$. $\mathrm{eh}$ renbergi were collected from 12 localities in Israel (Fig. 1) within 4 distinct climatic regimes and $41(91 \%)$ were infected with $1-5$ species of coccidians representing 4 species of eimerians and 1 species of isosporan (Table I). Of those infected, $26(63 \%)$ had multiple infections (Table II) and 3 of the eimerian species and 1 isosporan species appear to be new. Eimeria elliptica is described for the first time from $S$. ehrenbergi, and the occurrence in Israel constitutes a new geographic record for this species.

\section{Eimeria anzanensis n. sp.}

(Figs. 2-4, 13)

\section{Description}

Oocyst ellipsoidal (Fig. 3), wall $\sim 1.3$, composed of 2 layers: outer layer smooth, pale yellow in transmitted light, $\sim 1 / 2$ of total thickness; inner layer transparent, smooth; micropyle and oocyst residuum absent, but small, refractile polar body sometimes present $(19 / 50$, $38 \%$; Fig. 3); sporulated oocysts $(n=50) 18.3 \times 12.5$ (14-22 $\times 10-16)$ with length : width ratio (=shape index, SI) $1.4(1.05-1.9)$; sporocysts $(n=50)$ elongateovoidal, $7.3 \times 4.9(5-10 \times 3-7)$ with SI $1.5(1.1-2.0)$; Stieda body present (Figs. 2, 4), but sub- and parastieda bodies absent; sporocyst residuum of granules that appear in clusters lying along center of sporocyst (Figs. $2,4)$; sporozoites have large posterior refractile body.

\section{Taxonomic summary}

Type host: Spalax ehrenbergi Nehring $(2 \mathrm{n}=60)$.

Type locality: Anza, Israel, $55 \mathrm{~km}$ SE of Haifa.

Prevalence: Found in 39 of $45(87 \%) S$. ehrenbergi superspecies including 8 of $10(80 \%)$ from chromosomal species $2 n=52,6$ of $8(75 \%)$ from species $2 n$ $=54,13$ of $15(87 \%)$ from species $2 n=58$, and all 12 $(100 \%)$ from species $2 n=60$. feces.

Site of infection: Unknown, oocysts collected from

Material deposited: Phototype (see Bandoni and Duszynski, 1988) of sporulated oocysts in the U.S. National Museum Parasite Collection, Beltsville, Maryland, (USNMPC) no. 82497; symbiotype (see Frey et al., 1992) in IEUH as catalogue number E. Nevo, \#D1500 .

Etymology: The nomen triviale is derived from the locality from which the first infected animal occurred and -ensis (L., belonging to).

\section{Remarks}

Sporulated oocysts of $E$. anzanensis resemble in shape those of Eimeria celebii Sayin, 1980, from S. ehrenbergi collected in Turkey and those of E. elliptica and Eimeria lalahanensis Sayin, Dincer, and Meric, 1977, both from Spalax leucodon Nordmann, also found in Turkey. They differ from those of $E$. celebii by having

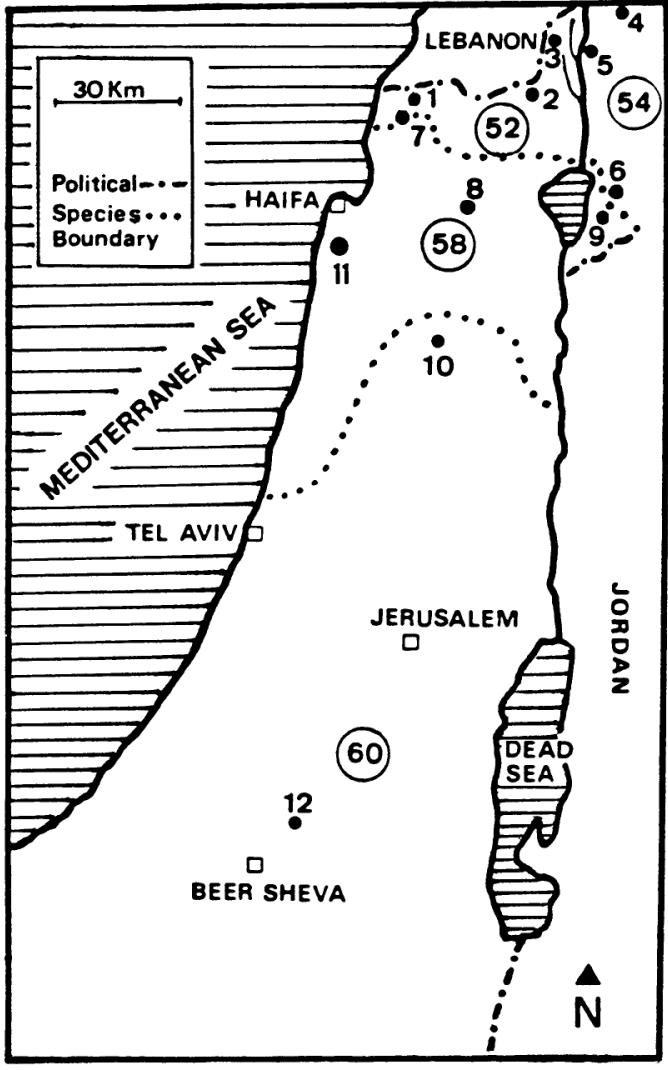

FIGURE 1. Distribution of 4 chromosomal species $(2 n=52,54,58,60)$ of Spalax ehrenbergi superspecies in Israel. Numbers in open circles indicate the 4 chromosomal species; small numbers next to closed circles indicate the 12 collection localities used in this study. 1, Maalot; 2, Kerem Ben Zimra; 3, Kiryat Shemona; 4, Hermon; 5, Quneitra; 6, El-Al; 7, Kabri; 8, Zipori; 9, Afiq; 10, Anza; 11, Carmel; 12, Lahav.

a stouter oocyst (SI 1.4 vs. 1.6) with ovoidal (vs. ellipsoidal) sporocysts, and in the presence of a prominent refractile body in each sporozoite, which is missing in $E$. celebii. They differ from those of $E$. elliptica by lacking 2 prominent polar bodies and in having larger sporocysts $(9.4 \times 6.8$ vs. $8.2 \times 5.1)$, which are ovoidal rather than ellipsoidal, with a residuum composed of multiple granules vs. 3-5 small granules. They differ from those of $E$. lalahanensis by having smaller oocysts with fewer polar bodies, in sporocyst shape, and in the size and shape of the sporocyst residuum.

Eimeria elliptica Sayin, Dincer, and Meric, 1977 (Fig. 5)

\section{Description}

Oocyst ellipsoidal with 2 walls of uniform thickness, $\sim 1.0$ : outer wall smooth, pale yellow, $\sim 1 / 2$ of total thickness; inner wall smooth, transparent; micropyle and oocyst residuum absent, but 1 (common) to 2 (rare) large, refractile polar bodies present; sporulated oocysts 
TABle I. Coccidian species found in 45 blind mole-rats, Spalax ehrenbergi superspecies, collected from 12 localities in 4 climatic regions in Israel.

\begin{tabular}{|c|c|c|c|}
\hline $\begin{array}{l}\text { Climatic region } \\
\text { Host population* }\end{array}$ & $\begin{array}{c}\text { Number infected/ } \\
\text { number examined (\%) }\end{array}$ & $\begin{array}{l}\text { Number of } \\
\text { chromosomes } \\
\text { (2n) }\end{array}$ & $\begin{array}{l}\text { Coccidian } \\
\text { species } \dagger\end{array}$ \\
\hline \multicolumn{4}{|l|}{ Cool-humid } \\
\hline Maalot (1) & $3 / 4 \quad(75 \%)$ & 52 & I, II \\
\hline Kerem Ben Zimra (2) & $1 / 2 \quad(50 \%)$ & 52 & I \\
\hline Kiryat Shemona (3) & $4 / 4 \quad(100 \%)$ & 52 & I, II \\
\hline \multicolumn{4}{|l|}{ Cool-semidry } \\
\hline Hermon (4) & $2 / 2 \quad(100 \%)$ & 54 & I, II \\
\hline $\mathrm{El}-\mathrm{Al}(6)$ & $1 / 1 \quad(100 \%)$ & 54 & II \\
\hline Quneitra (5) & $5 / 5 \quad(100 \%)$ & 54 & I, II, III \\
\hline \multicolumn{4}{|l|}{ Warm-humid } \\
\hline Kabri (7) & $2 / 2 \quad(100 \%)$ & 58 & $\mathrm{I}, \mathrm{V}$ \\
\hline Zipory (8) & $2 / 2 \quad(100 \%)$ & 58 & I, II, V \\
\hline Carmel (11) & $6 / 7 \quad(86 \%)$ & 58 & I, II, IV, V \\
\hline Afiq (9) & $3 / 4 \quad(75 \%)$ & 58 & I, II, III, IV \\
\hline \multicolumn{4}{|l|}{ Warm-dry } \\
\hline Lahav (12) & $2 / 2 \quad(100 \%)$ & 60 & I, II, III, IV, V \\
\hline Anza (10) & $10 / 10(100 \%)$ & 60 & I, II, III, IV \\
\hline Total 12 localities & $41 / 45(91 \%)$ & 4 species & 5 species \\
\hline
\end{tabular}

* Numerals refer to geographic localities shown in Figure 1.

† I, Eimeria anzanensis; II, Eimeria elliptica; III, Eimeria spalacensis; IV, Eimeria carmelensis; V, Isospora spalacensis.

$(\mathrm{n}=50) 15.3 \times 10.6(11-24 \times 7-13)$ with SI 1.45 $(1.0-2.0)$; sporocysts $(n=50)$ ovoidal, $6.0 \times 4.0(4-8$ $\times 3-5)$ with SI $1.5(1.2-2.5)$; Stieda body present, but sub- and parastieda bodies absent; sporocyst residuum present, composed of small granules that lie in narrow band along center of sporocyst, between sporozoites; sporozoites each with large, posterior refractile body.

\section{Taxonomic summary}

Prevalence: Found in 25 of 45 (56\%) S. ehrenbergi superspecies including 3 of $10(30 \%)$ from chromosomal species $2 n=52,4$ of $8(50 \%)$ from species $2 n$ $=54,10$ of $15(67 \%)$ from species $2 n=58$, and 8 of $12(67 \%)$ from species $2 n=60$. feces.

Site of infection: Unknown, oocysts collected from

\section{Remarks}

This eimerian species was first described from the herbivorous mole-rat, $S$. leucodon, collected in Turkey by Sayin et al. (1977). The oocysts we saw differ from the original description only by having 2 walls vs. 1 in the original description, but the total wall thickness is the same. Other than minor differences in size, the oocysts we saw otherwise were identical to those described by Sayin et al. (1977) as E. elliptica.

\section{Eimeria spalacensis n. sp.}

(Figs. 6, 7, 12)

\section{Description}

Oocyst ovoidal with 2 obvious walls, $\sim 1.6$ : outer wall smooth, but appears slightly striated under trans-

TABLE II. Infection patterns of coccidians in blind mole-rats, Spalax ehrenbergi, as host genetic diversity increases $(2 n=52 \rightarrow 60)$ toward more unpredictable environmental extremes (cool/humid $\rightarrow$ dry/hot).

\begin{tabular}{|c|c|c|c|}
\hline $\begin{array}{l}\text { Climatic region } \\
\text { (karyotype, } 2 n \text { ) }\end{array}$ & $\begin{array}{c}\text { Number infected/ } \\
\text { number examined } \\
(\%)\end{array}$ & $\begin{array}{l}\text { Coccidian } \\
\text { species } \\
\text { present* }\end{array}$ & Infection pattern $\dagger$ \\
\hline Cool-humid $(2 n=52)$ & $8 / 10(80)$ & I, II & $2(0), 5(\mathrm{I}), 3(\mathrm{I}, \mathrm{II})$ \\
\hline Cool-semidry $(2 n=54)$ & $8 / 8 \quad(100)$ & I-III & $\begin{array}{l}3 \text { (I), } 2 \text { (II), } 2 \text { (I, II), } \\
1 \text { (I, III) }\end{array}$ \\
\hline Warm-humid $(2 n=58)$ & $13 / 15(87)$ & $\mathbf{I}-\mathbf{V}$ & $\begin{array}{l}2(0), 2 \text { (I), } 6 \text { (I, II), } \\
1 \text { (I, V), } 2 \text { (I, II, V), } \\
1 \text { (I-IV), } 1 \text { (I-III, V) }\end{array}$ \\
\hline Warm-dry $(2 n=60)$ & $12 / 12(100)$ & $\mathbf{I}-\mathbf{V}$ & $\begin{array}{l}2 \text { (I), } 5 \text { (I, II), } 2 \text { (I, III), } \\
2 \text { (I-IV), } 1 \text { (I-V) }\end{array}$ \\
\hline
\end{tabular}

* I, Eimeria anzanensis; II, Eimeria elliptica; III, Eimeria spalacensis; IV, Eimeria carmelensis; V, Isospora spalacensis.

$\dagger$ Number of mole-rats followed by coccidian species present in parentheses. 


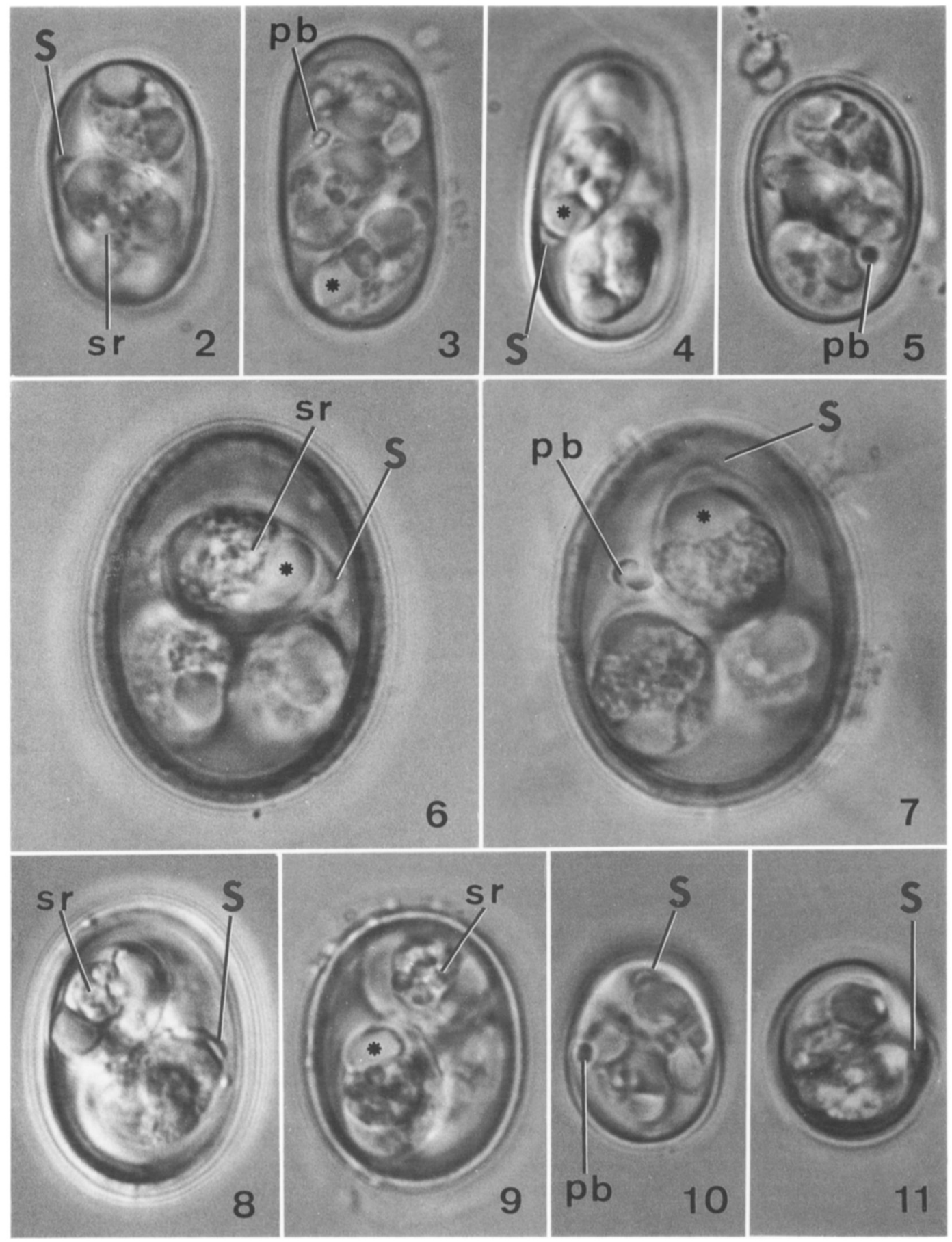

Figures 2-11. Photomicrographs of sporulated oocysts obtained from the feces of Spalax ehrenbergi superspecies in Israel. 2-4. Eimeria anzanensis n. sp. 5. Eimeria elliptica. 6, 7. Eimeria spalacensis $\mathrm{n} . \mathrm{sp} .8,9$. Eimeria carmelensis n. sp. 10, 11. Isospora spalacensis $\mathrm{n}$. sp. Scale bar $=10 \mu \mathrm{m}$ for all figures. Abbreviations: $\mathrm{S}$, Stieda body; sr, sporocyst residuum; pb, polar body; *, refractile body of sporozoite. 

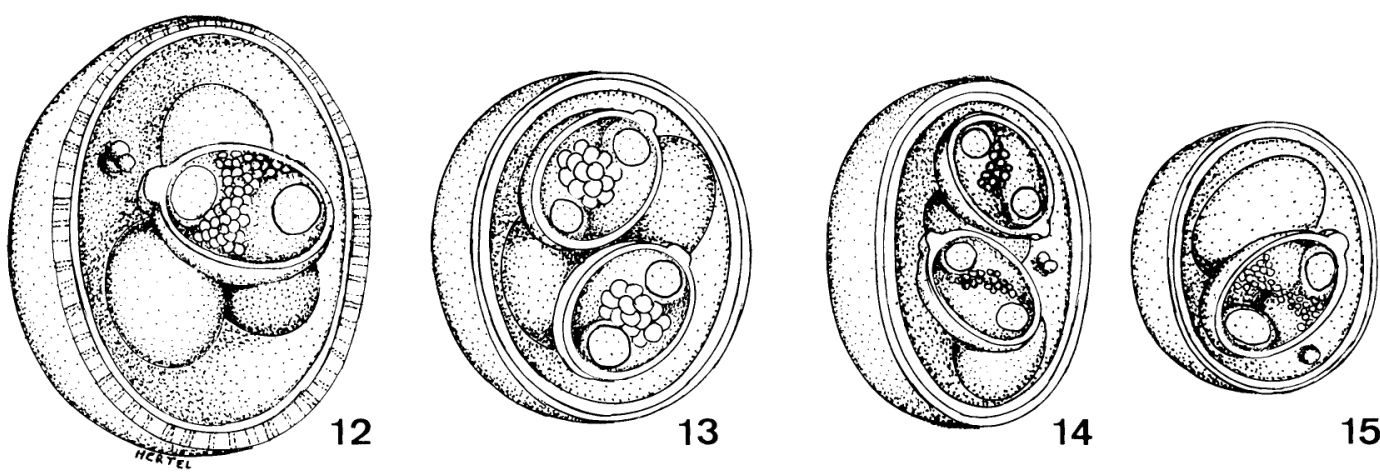

Figures 12-15. Composite line drawings of sporulated oocysts of coccidia collected from feces of Spalax ehrenbergi superspecies from Israel. 12. Eimeria spalacensis. 13. Eimeria anzanensis. 14. Eimeria carmelensis. 15. Isospora spalacensis. Scale bar $=10 \mu \mathrm{m}$.

mitted light (Figs. 6, 7), $\sim 1 / 2-2 / 3$ of the total thickness; wall is not of uniform thickness, thinning slightly at the pointed end of oocyst; micropyle and oocyst residuum absent, but 1-3 large, refractile polar bodies ( 1.5 $\times 3)$ are present (Fig. 7); sporulated oocysts $(n=50)$ $23.4 \times 18.3(17-29 \times 12-21)$ with SI $1.3(1.0-1.7)$; sporocysts $(n=50)$ ovoidal, $9.4 \times 6.8(6-12 \times 4-10)$ with SI 1.4 (1.1-1.9); Stieda body present (Figs. 6, 7), but sub- and parastieda bodies absent; sporocyst residuum consists of large coarse granules that lie in band across center of sporocyst (Figs. 6, 7); sporozoites with 1 large posterior refractile body.

\section{Taxonomic summary}

Type host: Spalax ehrenbergi Nehring $(2 \mathrm{n}=60)$.

Type locality: Anza, Israel, $55 \mathrm{~km}$ SE of Haifa.

Prevalence: Found in 7 of 45 (16\%) S. ehrenbergi superspecies including 1 of $8(12.5 \%)$ from chromosomal species $2 n=54,1$ of $15(7 \%)$ from species $2 n$ $=58$, and 5 of $12(42 \%)$ from species $2 n=60$.

Site of infection: Unknown, oocysts collected from feces.

Material deposited: Phototypes of sporulated oocysts in USNMPC, no. 82499; symbiotype in IEUH no. E. Nevo, \#D-1640.

Etymology: The nomen triviale is derived from the generic name of the host and -ensis (L., belonging to).

\section{Remarks}

Sporulated oocysts of this eimerian species are the largest of the 4 species found in $S$. ehrenbergi from Israel. Of all the eimerians described from species of Spalax, oocysts of this form are similar in size and shape only to those of Eimeria oytuni Sayin, 1980, described from $S$. ehrenbergi in Turkey, but they differ by lacking a micropyle, by having polar bodies, and by the size and shape of the sporocyst, its Stieda body, and residuum.

\section{Eimeria carmelensis n. sp.}

(Figs. 8, 9, 14)

\section{Description}

Oocyst subspheroidal to ellipsoidal (Figs. 8, 9) with wall $\sim 1.1$, composed of 2 layers: outer layer smooth, $\sim 1 / 3$ of total thickness; inner layer transparent, smooth; micropyle, oocyst residuum, and polar body absent; sporulated oocysts $(\mathrm{n}=50) 19.1 \times 16.5(14-25 \times 11-$ 20) with SI $1.2(1.05-1.4)$; sporocysts $(n=50)$ spheroidal to ellipsoidal $8.6 \times 6.2(6-13 \times 4-8)$ with SI 1.4 (1.0-1.9); Stieda body present (Fig. 9), but difficult to see in most oocysts due to tight packing of sporocysts (Fig. 9), sub- and parastieda bodies absent; sporocyst residuum a mass of large granules covering center of sporocyst (Figs. 8, 9); sporozoites with large, posterior refractile body.

\section{Taxonomic summary}

Type host: Spalax ehrenbergi Nehring $(2 \mathrm{n}=58)$.

Type locality: Carmel, Israel, Mukhraka Monastery, $20 \mathrm{~km}$ SE of Haifa.

Prevalence: Found in 5 of 45 (11\%) S. ehrenbergi superspecies including 2 of $15(13 \%)$ from chromosomal species $2 n=58$ and 3 of $12(25 \%)$ from species $2 \mathrm{n}=60$.

Site of infection: Unknown, oocysts collected from feces.

Material deposited: Phototypes of sporulated oocysts in USNMPC, no. 82498; symbiotype in IEUH no. E. Nevo, \#G-943.

Etymology: The nomen triviale is derived from the general locality in Israel from which the first infected animal was examined and -ensis (L., belonging to).

\section{Remarks}

Oocysts of this species most closely resemble those of Eimeria tuzdii Sayin, Dincer, and Meric, 1977, described from $S$. leucodon in Turkey, in size and shape of their oocysts. They differ, however, by the lack of a striated oocyst outer wall, by not having 2 polar bodies, and by the size and shape of the sporocysts and their Stieda bodies.

\section{Isospora spalacensis n. sp.} (Figs. 10, 11, 15)

\section{Description}

Oocyst ellipsoidal (Fig. 10) with wall $\sim 0.8$, composed of 2 layers: outer layer smooth, pale yellow, $\sim 1 / 3$ of total thickness; inner layer transparent, smooth; mi- 
cropyle and oocyst residuum absent, but $1-2$ polar bodies present (Fig. 10), $\sim 1.5$; sporulated oocysts $(\mathrm{n}=25)$ $14.6 \times 11.0(12-17 \times 9-14)$ with SI $1.3(1.1-1.7)$; sporocysts $(n=25)$ ellipsoidal to ovoidal, $8.5 \times 4.5$ (7.5-11 x 4-7) with SI 1.95 (1.6-2.3); Stieda body present, difficult to see due to tight packing of sporocysts in oocyst (Figs. 10,11), but sub- and parastieda bodies absent; sporocyst residuum of small granules in narrow band across middle of sporocyst; sporozoites with larger, posterior refractile body (Figs. 10, 11).

\section{Taxonomic summary}

Type host: Spalax ehrenbergi Nehring $(2 \mathrm{n}=58)$.

Type locality: Kabri, Israel, $28 \mathrm{~km} \mathrm{NE}$ of Haifa.

Prevalence: Found in 5 of 45 (11\%) S. ehrenbergi superspecies including 4 of $15(27 \%)$ from chromosomal species $2 n=58$ and 1 of $12(8 \%)$ from species $2 \mathrm{n}=60$. feces.

Site of infection: Unknown, oocysts collected from

Material deposited: Phototypes of sporulated oocysts in USNMPC, no. 82500; symbiotype in IEUH no. E. Nevo, \#G-910.

Etymology: The nomen triviale is derived from the generic name of the host and -ensis (L., belonging to).

\section{Remarks}

Only 1 isosporan, Isospora anatolicum Sayin, Dincer, and Meric, 1977, has been described from molerats; it was found in only 1 of $96(1 \%) S$. leucodon from Turkey. Neither the oocysts nor sporocysts of the form reported here resemble those of I. anatolicum.

\section{DISCUSSION}

Mole-rats are truly subterranean rodents that can be distinguished from all others by the absence of external openings for their eyes, though small eyes are present beneath the skin. They do not live in true deserts, but they can inhabit any type of soil, except sand dunes, that receives $>100$ $\mathrm{mm}$ of annual precipitation. They are primarily herbivorous, feeding on the underground parts of plants (i.e., corms, bulbs, roots), and they rarely venture above ground. Elaborate tunnel systems, used mainly in the search for food, may be tens of meters long, and in their eastern Mediterranean range these rodents are considered serious agricultural pests. Each burrow system has several chambers used for various purposes (e.g., nesting, storing food) including 1 or more chambers used only for defecation (Nevo, 1961).

The taxonomy of this host group has not been resolved. Honacki et al. (1982) placed the molerats in their own family (Spalacidae) containing only Spalax with 3 species (also see Anderson and Jones, 1984), whereas Nowak (1991) separated the mole-rats into 3 genera (Spalax, Nannospalax, Myospalax) containing 14 species.
Karyological studies have demonstrated the existence of about 30 chromosomal species of $S$. leucodon (=Nannospalax leucodon) in the Balkans, Russia, and Asia Minor (Savic and Nevo, 1990), as well as 4 of $S$. ehrenbergi in Israel; the latter 4 chromosomal races are known now to be distinct species, all closely related (Nevo and BarEl, 1976; Nevo et al., 1982, 1988; Nevo, 1985, 1991; Savic and Nevo, 1990). This complex of biological species is relatively young (Pleistocene in age), and in all previous molecular and organismal analyses (see Nevo [1991] for review) the $2 \mathrm{n}=52$ and 54 are the older pairs, whereas the $2 n=58$ and 60 are the younger pairs.

Prior to our work, there were already 16 coccidian species described from mole-rats: Veisov (1975) described 3 eimerian species from $S$. leucodon in what was the U.S.S.R.; Sayin et al. (1977) described 5 eimerian species and 1 isosporan species from $96 \mathrm{~S}$. leucodon collected in Turkey; and Sayin (1980) described 7 eimerian species from $41 S$. ehrenbergi, also from Turkey. Whatever the actual number of species of mole-rats, given the prevalence, intensity, and variety of infection with coccidians in only the 2 nominal species (and 4 chromosomal species) examined for coccidia to date, it appears that the chance of discovery of additional species is high as more mole-rats are studied.

Speciation of the $S$. ehrenbergi complex of mole-rats in Israel into 4 chromosomal species $(2 \mathrm{n}=52,54,58,60)$ has been studied in great detail and is known to be intimately associated, and statistically correlated, with both the macroand microclimatic structure of the country as follows: $2 n=52$ primarily in the cool-humid upper Galilee Mountains; $2 n=54$ in the coolsemidry Golan Heights; $2 \mathrm{n}=58$ in the warmhumid lower Galilee Mountains and central coastal plain; and $2 n=60$ in the warm-dry southern coastal plain and northern Negev Desert (Nevo, 1985, 1986, 1991; also see Table II). This ecological speciation of $S$. ehrenbergi into increasingly arid environments involves climatically coadapted genomic and organismal adaptations (Nevo, 1991).

Genetic diversity of $S$. ehrenbergi is known to increase progressively southward and eastward in Israel, toward the desert. This increased diversity can be measured both chromosomally $(2 \mathrm{n}=52 \rightarrow 58 \rightarrow 60$ southward and $2 \mathrm{n}=52 \rightarrow$ 54 eastward [Nevo, 1985, 1991]) and genically (heterozygosity $[\mathrm{H}]=0.035,0.037$, and 0.069 for $2 \mathrm{n}=52,58$, and 60 , respectively [Nevo and 
Cleve, 1978]). This trend of increasing genetic diversity toward climatically unpredictable environments (i.e., increased heat and drying) is shared by many plants and animals in Israel (Nevo, 1983; Nevo and Beiles, 1988) and seems to be correlated positively with both parasite prevalence and parasite success in these hosts. Using percentage of infected mole-rats as a measure of infectivity, data from 2 previous parasite surveys (Costa and Nevo, 1969 [ectoparasites]; Wertheim and Nevo, 1971 [nematodes]) were reexamined in a recent study on class II major histocompatibility complex (Mhc) molecules (Nevo and Beiles, 1992). The results showed that both mite and nematode infections increased with the climatic index, i.e., with both humidity and temperature; both infections correlated positively with the $\mathrm{H}$ of 2 class II Mhc genes; and that $\mathrm{H}$ was highest in the regions of most infection, occupied by the $2 n=58$ species. The conclusion drawn was that the evolutionary forces responsible for the Mhc class II 2 gene polymorphisms include selection for increased $\mathrm{H}$ as a defense strategy against ecto- and endoparasite infections.

When our results are considered in light of this previous work on the same host model, other interpretations also may be possible. In addition to increasing environmental unpredictability contributing to elevated genic and chromosomal diversity, such an environment also should be more stressful physiologically to the hosts that live there, and this stress apparently makes them more susceptible to coccidial infection in at least 2 ways: the number of individuals in the population that harbor an infection (prevalence) is increased, and the number of coccidian species found in these hosts also is increased. Thus, we found 5 coccidian species in our $2 n=58$ and $2 n$ $=60$ species, whereas only 2 eimerian species were found in $2 n=52$ mole-rats and 3 eimerian species in the $2 n=54$ species. Also, mole-rats that live in warm climates, i.e., the species with $2 n=58$ and $2 n=60$, were more often infected with $2-5$ coccidian species concurrently $(21 / 27$, $78 \%$ ), whereas those with $2 n=52$ and $2 n=54$ had fewer multiple infections $(6 / 18,33 \%)$.

A parallel observation was made earlier on the coccidial burdens of another subterranean rodent, the tuco-tuco (Ctenomys spp.), in Bolivia, South America (Gardner and Duszynski, 1990). Most species of Ctenomys are highly subterranean, exhibit low vagility, occur in relatively low population densities, and, as a group, exhibit the highest known chromosomal variation for all mammals (Cook et al., 1990). The 7 tuco-tuco species examined for coccidia by Gardner and Duszynski (1990) occurred in 4 habitat types in Bolivia: warm-humid, a palm-nut/savanna region of east-central Bolivia (Ctenomys boliviensis Waterhouse, 1848; Ctenomys steinbachi Thomas, 1907); warm-dry, a lowland dry Chaco thorn forest (Ctenomys conoveri Osgood, 1946); coolmoist, a montane/grassland habitat (Ctenomys frater Thomas, 1902); and cold-dry, the high altitude $(>4,000 \mathrm{~m}) /$ puna habitat of the Altiplano (Ctenomys leucodon Waterhouse, 1848; Ctenomys lewisi Thomas, 1926; Ctenomys opimus Wagner, 1848). Tuco-tucos in the harshest of these environments, the Altiplano (essentially a cold desert), had higher prevalences of infection $(80 \%)$ than tucos in the other 3 habitat types $(33 \%, 33 \%$, and $27 \%$, respectively). Also, the tucos on the Altiplano were infected by 4 species of Eimeria, and nearly half of those with coccidia $(49 \%)$ were infected with multiple species, whereas no tuco ( $0 \%$ of 88 infected animals) in the other 3 environments was infected with more than 1 eimerian (Eimeria opimi Lambert, Gardner, and Duszynski, 1988).

The pattern seen in the above studies on subterranean rodents in some ways is counterintuitive. For example, it is known that parasites evolve with their hosts over evolutionary time and often reach compromises along the way; thus, evolutionarily older hosts (e.g., $2 \mathrm{n}=52$ and 54 mole-rats), especially those that are genically conservative (e.g., moles, rabbits), might support more parasites than evolutionarily younger hosts undergoing rapid genic change (e.g., many mice species). This should apply especially for intracellular parasites that are closely tied to the genome of their host as are the coccidia; i.e., the parasites simply have a chance to "catch up" to changes in their environment (their hosts' epithelial cells), to adapt accordingly, and eventually to speciate. Such is certainly true for the moles (Insectivora) examined to date for coccidians: of 195 moles in 8 species and 6 genera from England, Japan, and the U.S.A., 183 (94\%) were infected with coccidia and $153(84 \%)$ of those infected had oocysts from 2 to 8 coccidian species in their feces when examined (Duszynski, 1989). Rabbits also are known to be heavily infected with many species of coccidia almost all the time (Duszynski and Marquardt, 1968), whereas many mammals that speciate more frequently (mice, bats, etc.) tend to have lower prevalences of in- 
fection and seldom harbor more than 1 or 2 coccidian species at a time (Duszynski, 1986).

However, a different mechanism, or more likely a combination of several factors, seems to regulate coccidial infections in subterranean rodents. In addition to living a rather solitary existence in their burrow systems, the ctenomyids in South America and the spalacids in southeast Europe both seem to approach unpredictable environments (deserts, cold, and hot respectively) with increased genetic diversity and, for whatever reasons, this increased genetic diversity is accompanied both by increased infec tion prevalences and by more frequent infection with multiple coccidial species, especially in the most inhospitable environments. This is certainly a topic that deserves more study.

Another topic that deserves attention is the mechanism of transmission of oocysts among subterranean rodents in hot and cold deserts. Clearly, the burrow provides moisture anc protection from ultraviolet radiation, both conditions that would be conducive to oocyst development and longevity; however, tucos and mole-rats are mostly solitary individuals that $d c$ not share burrows with others of their species and the question of how so many of them can be infected, and with so many species, in such environments remains to be answered.

\section{ACKNOWLEDGMENTS}

Sincere thanks are due W. D. Hamilton and Joel Peck, Oxford University, for their helpful and thoughtful comments on an earlier draft of this manuscript and to Lynn Hertel for her line drawings of our new species. We also thank the Israeli Discount Bank Chair of Evolutionary Biology, and the Ancell-Teicher Research Foundation for Genetics and Molecular Evolution established by Florence and Theodore Baumritter of New York, for financial support of this research.

\section{LITERATURE CITED}

ANDERSON, S., AND J. K. JONES, JR. (eds.). 1984. Orders and families of Recent mammals of the world. John Wiley and Sons, New York, p. 372.

BANDONI, S. M., AND D. W. DuszYNSKI. 1988. A plea for improved presentation of type material for coccidia. Journal of Parasitology 74: 519-523.

Brooks, D. R. 1979. Testing the context and extent of host-parasite coevolution. Systematic Zoology 28: 299-307.

Cook, J. A., S. Anderson, AND T. L. Yates. 1990. Notes on Bolivian mammals 6. The genus Cten- omys (Rodentia, Ctenomyidae) in the highlands. American Museum Novitates 2980: 1-27.

Costa, M., AND E. Nevo. 1969. Nidicolous arthropods associated with different chromosomal types of Spalax ehrenbergi Nehring. Zoological Journal of the Linnean Society 48: 199-215.

DUSZYNSKI, D. W. 1986. Host specificity in the coccidia of small mammals: Fact or fiction? In Advances in protozoological research, Vol. 33, Symposium Biological Hungarica, M. Bereczky (ed.). Akademiai Kiado, Budapest, p. 325-337.

- 1989. Coccidian parasites (Apicomplexa: Eimeriidae) from insectivores. VIII. Four new species from the star-nosed mole, Condylura cristata. Journal of Parasitology 75: 514-518.

$\longrightarrow$, G. EASTHAM, AND T. L. YATES. 1982. Eimeria from jumping mice (Zapus spp.): A new species and genetic and geographic features of $Z$. hudsonius luteus. Journal of Parasitology 68: 1146-1148. , AND W. C. MARQUARDT. 1968. Eimeria (Protozoa: Eimeriidae) of the cottontail rabbit $S y l v i$ lagus audubonii in northeastern Colorado, with descriptions of three new species. Journal of Protozoology 16: 128-137.

FAIR, J. M., G. D. SCHMIDT, AND G. WertheIM. 1990. New species of Andrya and Paranoplocephala (Cestoidea: Anoplocephalidae) from voles and mole-rats in Israel and Syria. Journal of Parasitology 76: 641-644.

Frey, J. K., T. L. Yates, D. W. Duszynski, W. L. GANNON, AND S. L. Gardner. 1992. Designation and curatorial management of type host specimens (symbiotypes) for new parasite taxa. Journal of Parasitology 78: 930-932.

Gardner, S. L., AND D. W. DuszYNSKi. 1990. Polymorphism of eimerian oocysts can be a problem in naturally infected hosts: An example from subterranean rodents in Bolivia. Journal of Parasitology 76: 805-811.

Honacki, J. H., K. E. Kinman, and J. W. KoepPl (eds.). 1982. Mammal species of the world. Association of Systematics Collections, Lawrence, Kansas, p. 477.

Nevo, E. 1961. Observations on Israeli populations of the mole rat Spalax e. ehrenbergi Nehring 1898. Mammalia 25: 127-144.

- 1983. Population genetics and ecology: The interface. In Evolution from molecules to man, D. Bendall (ed.). Cambridge University Press, Cambridge, p. 287-321.

- 1985. Speciation in action and adaptation in subterranean mole rats: Patterns and theory. Bollettino di Zoologia 52: 65-95.

-1986. Mechanisms of adaptive speciation at the molecular and organismal levels. In Evolutionary processes and theory, S. Karlin and E. Nevo (eds.). Academic Press, Inc., New York, p. 439474.

1991. Evolutionary theory and processes of active speciation and adaptive radiation in subterranean mole rats, Spalax ehrenbergi superspecies, in Israel. Evolutionary Biology 25: 1-125.

$\longrightarrow$, AND H. BAR-EL. 1976. Hybridization and speciation in fossorial mole-rats. Evolution 30: 831-840. 
- AND A. BEILES. 1988. Genetic parallelism of protein polymorphism in nature: Ecological test of the neutral theory of molecular evolution. Biological Journal of the Linnean Society 35: 229_ 245.

, AND - 1992. Selection for class II $M h c$ heterozygosity by parasites in subterranean mole rats. Experientia 48: 512-515.

, AND H. Cleve. 1978. Genetic differentiation during speciation. Nature 275: 125-126.

, M. Corti, G. Heth, A. Beiles, and S. Simson. 1988. Chromosomal polymorphisms in subterranean mole rats: Origins and evolutionary significance. Biological Journal of the Linnean Society 33: 309-322.

-, G. Heth, ANd A. Beiles. 1982. Population structure and evolution in subterranean mole rats, Evolution 36: 1283-1289.

$\longrightarrow$, AND C. R. SHAw. 1972. Genetic variation in a subterranean mammal, Spalax ehrenbergi. Biochemical Genetics 7: 235-241.

NowAK, R. M. 1991. Walker's mammals of the world, 5 th ed. The Johns Hopkins University Press, Baltimore, Maryland, p. 709-712.

Savic, I. R., AND E. Nevo. 1990. The Spalacidae:
Evolutionary history, speciation and population biology. In Evolution of subterranean mammals at the organismal and molecular levels, Proceedings of the Fifth International Theriological Congress (1989), E. Nevo and O. A. Reig (eds.). WileyLiss, New York, p. 129-153.

SAYIN, F. 1980. Eimeriidae of the herbivorous molerat, Spalax ehrenbergi Nehring. Journal of Protozoology 27: 364-367.

S. Dincer, AND I. Meric. 1977. Coccidia (Protozoa: Eimeriidae) of the herbivorous molerat, Spalax leucodon Nordmann. Journal of Protozoology 24: 210-212.

Veisov, A. M. 1975. Tri novykh vida koktsidii roda Eimeria iz gormogo ili belozobugo slepysha $S p a-$ lax leucodon Nordmann (1840). Izvesti i a Akademi i a Nauk Azerbaidzhanskoi SSR 4: 82-85.

WAHRMAN, J., C. Richler, R. GAMPERL, AND E. NeVo. 1985. Revisiting Spalax: Mitotic and meiotic chromosome variability. Israel Journal of Zoology 33: $15-38$.

Wertheim, G., AND E. Nevo. 1971. Helminths of birds and mammals from Israel: III. Helminths from chromosomal forms of the mole-rat, Spalax ehrenbergi. Journal of Helminthology 45: 161-169. 